\title{
STUDI PERBANDINGAN KARAKTERISTIK KIMIA DAN PETROGRAFI BATUBARA LAPANGAN X, CEKUNGAN SUMATERA SELATAN DAN LAPANGAN Y CEKUNGAN SUMATERA TENGAH INDONESIA
}

\section{CHEMICHAL AND PETROGRAPHIC CHARACTERISTIC OF COAL FROM X FIELD SOUTH SUMATERA BASIN AND Y FIELD CENTRAL SUMATERA BASIN INDONESIA - A COMPARATIVE STUDY}

\author{
Azmi Baihaqi ${ }^{1}$, Rita Susilawati ${ }^{2}$, Lili Fauzielly ${ }^{1}$, dan Budi Muljana ${ }^{1}$ \\ ${ }^{1}$ FakultasTeknik Geologi Universitas Padjadjaran \\ 2 Pusat Sumber Daya Mineral, Batubara dan Panas Bumi \\ azmibaihaqi123@gmail.com
}

\begin{abstract}
ABSTRAK
Karakteristik batubara dari dua wilayah prospek batubara di Sumatera dievaluasi dengan menggunakan metode kimia dan petrografi batubara. Penelitian terfokus pada evaluasi peringkat (tingkat pembatubaraan di daerah penelitian), tipe (komposisi material organik dan lingkungan pengendapan batubara) serta grade (kandungan material inorganik yang bisa berpengaruh terhadap proses utilisasi) batubara. Lapangan $\mathrm{X}$ memiliki lapisan batubara yang merupakan bagian dari Formasi Muaraenim dan Kasai Cekungan Sumatera Selatan sedangkan batubara pada lapangan $Y$ merupakan bagian dari Formasi Petani Cekungan Sumatera Tengah. Sebanyak enam percontoh batubara dari lapangan $X$ dan 8 percontoh dari lapangan $Y$ digunakan dalam penelitian ini. Hasil penelitian menunjukkan bahwa kedua lapangan memiliki batubara dengan karakteristik yang berbeda. Walaupun batubara di kedua daerah termasuk dalam kategori lignit, nilai rata-rata reflektansi huminit batubara Lapangan $Y$ sedikit lebih tinggi dari lapangan $X$. Hal ini mengindikasikan bahwa batubara lapangan $Y$ mengalami pengaruh peningkatan termperatur dan pembebanan yang lebih tinggi dari lapangan $\mathrm{X}$. Berdasarkan hasil analisis komposisi maseral, batubara lapangan $\mathrm{X}$ dapat dibedakan ke dalam 3 fasies: fasies 1 (huminit $>90 \%$, kandungan inertinit dan liptinit $<10 \%$ ), fasies II (huminit $80 \%$ s.d. $90 \%$, inertinite $10 \%$ s.d. $15 \%$, dan liptinit $10 \%$ ) serta fasies III (huminit $75 \%$ s.d. $85 \%$, inertinit $15 \%$ s.d. $20 \%$ dan liptinit $<10 \%$ ). Sementara batubara lapangan $Y$ lebih homogen dan dapat digolongkan ke dalam satu fasies (huminit $>90 \%$ dan liptinit serta inertinite $<10 \%$ ). Hasil plot Gelification index (GI) dan Tissue preservation index (TPI) menunjukkan bahwa batubara lapangan $X$ diendapkan pada lingkungan limnic-marsh hingga limno telmatic sedangkan batubara lapangan $Y$ pada lingkungan limnic hingga telmatic marsh. Banyaknya konkresi pirit pada batubara lapangan $Y$ mengindikasikan bahwa batubara tersebut mendapat pengaruh laut yang lebih besar daripada batubara lapangan $X$ Batubara di kedua lapangan dapat dianggap sebagai batubara grade tinggi atau batubara bersih karena memiliki kandungan sulfur $(<10 \%)$ dan abu yang relatif rendah $(<10 \%)$. Hanya satu percontoh (SJ2) yang memiliki kadar abu tinggi (>50\%) menunjukkan bahwa percontoh tersebut bukan batubara. Sebagai kesimpulan, perbedaan karakteristik batubara lapangan $X$ dan $Y$ mendukung teori bahwa batubara dengan sejarah pengendapan yang berbeda akan menghasilkan karakteristik yang berbeda.
\end{abstract}

Kata kunci: karakteristik batubara, peringkat, tipe, mutu, lingkungan pengendapan

\section{ABSTRACT}

Using chemical and coal petrography analysis methods, this study aims to evaluate coal characteristics from two coal-bearing areas in Sumatera. The evaluation focuses on rank, type and grade of coal from both areas. Coal-bearing units in $X$ field are part of Muaraenim and 
Kasai Formation of South Sumatera Basin, while $Y$ field contains coal that belongs to Petani Formation of Central Sumatera Basin. Six coal samples from $X$ field and eight ones from $Y$ field were used in this study. The result of this research showed that the coals from the two areas differ in their characteristics. Although coal in both areas are lignite, the Rv of coal in $Y$ field is slightly higher than $X$ field suggesting that $Y$ coal may experienced higher temperature and buried deeper than $X$ coal. Based on its maceral composition, coal in $X$ field could be classified into 3 facies: facies I (huminit $>90 \%$, liptinite and inertinite $<10 \%$ ), facies 2 (huminit $80 \%$ s.d. $90 \%$, inertinite $10 \%$ s.d. $15 \%$ and liptinite 10\%) and facies 3 (huminit $75 \%$ s.d. $85 \%$, inertinite $15 \%$ s.d. $25 \%$ dan liptinite $<10 \%$ ). On the other hand, the coal maceral composition of $Y$ field is more uniform as such can be grouped into 1 facies (Huminit $>10 \%$, inertinite and liptinite <10\%). Plot of Tissue Preservation Index (TPI) and Gelification Index (GI) indicates that $X$ field coal was deposited in a limnic marsh to limno telmatic while $Y$ coal in limnic to telmatic marsh. The presence of pyrite concretions in coal of $Y$ field, suggest that coal in this field experienced more marine influenced than coal of $X$ field. Related to grade, both fields have relatively clean coals that low in ash and sulphur. Only SJ2 sample from $X$ field that contains high ash (>50\%), suggesting that the samples was not coal. To sum up, the difference in coal characteristic of $X$ and $Y$ areas supports the theory that coal from different depositional history will generate distinct characteristic.

Keywords: coal characteristics, rank, type, grade, depositional environment

\section{PENDAHULUAN}

Batubara adalah salah satu sumber energi yang keberadaanya cukup berlimpah di Indonesia. Karakteristik batubara dalam hal ini peringkat (rank), tipe (type) dan mutu (grade), adalah tiga paramater yang mempengaruhi kualitas serta pemanfaatan batubara (Speight, 2013). Karakteristik batubara ditentukan oleh berbagai hal di antaranya oleh proses geologi dan sejarah pembentukan batubara. Batubara yang mengalami sejarah pengendapan yang berbeda akan menghasilkan karakteristik yang juga berbeda (Diessel, 1992).

Peringkat batubara menunjukkan tingkat metamorfisma (pembatubaraan) yang dialami oleh tumbuhan pembentuk batubara (proto-coal) selama sejarah penimbunan (burial history). Peringkat batubara bergantung pada temperatur maksimum dan tekanan serta lamanya proto-coal terpapar oleh temperatur dan tekanan tersebut. Peningkatan peringkat direfleksikan oleh beberapa parameter di antaranya nilai reflektansi vitrinit/huminit $(\mathrm{Rv})$, nilai kalori, karbon tertambat (fixed carbon/FC) atau nilai zat terbang (volatile matter/VM). Secara teori, seiring dengan bertambahnya peringkat batubara maka nilai kalori dan nilai $\mathrm{Rv}$ akan bertambah, sementara nilai VM akan berkurang (Speight, 2013).

Tipe batubara menunjukkan karakteristik material organik penyusun batubara (kayu, daun, akar, alga dan lain-lain) berikut tingkat degradasi selama dan sebelum material organik tersebut mengalami pembatubaraan (Suarez dan Crelling, 2008). Tipe batubara juga bisa merefleksikan lingkungan pengendapan pada saat batubara tersebut terbentuk (Diessel, 1992). Sementara mutu dari batubara merefleksikan seberapa besar akumulasi material tumbuhan terbebas dari kontaminasi oleh material anorganik (mineral matter) baik selama dan sebelum mengalami proses penggambutan, setelah penimbunan, maupun selama proses pembatubaraan dan setelahnya (Suarez dan Crelling, 2008).

Tulisan ini dibuat dengan tujuan untuk mengetahui karakteristik peringkat, tipe dan mutu batubara dari dua lapangan prospek batubara yang berada di dua cekungan prospek batubara di Indonesia, di samping juga untuk membuktikan teori bahwa batubara yang memiliki sejarah pengendapan yang berbeda akan memiliki karakteristik yang juga berbeda. 


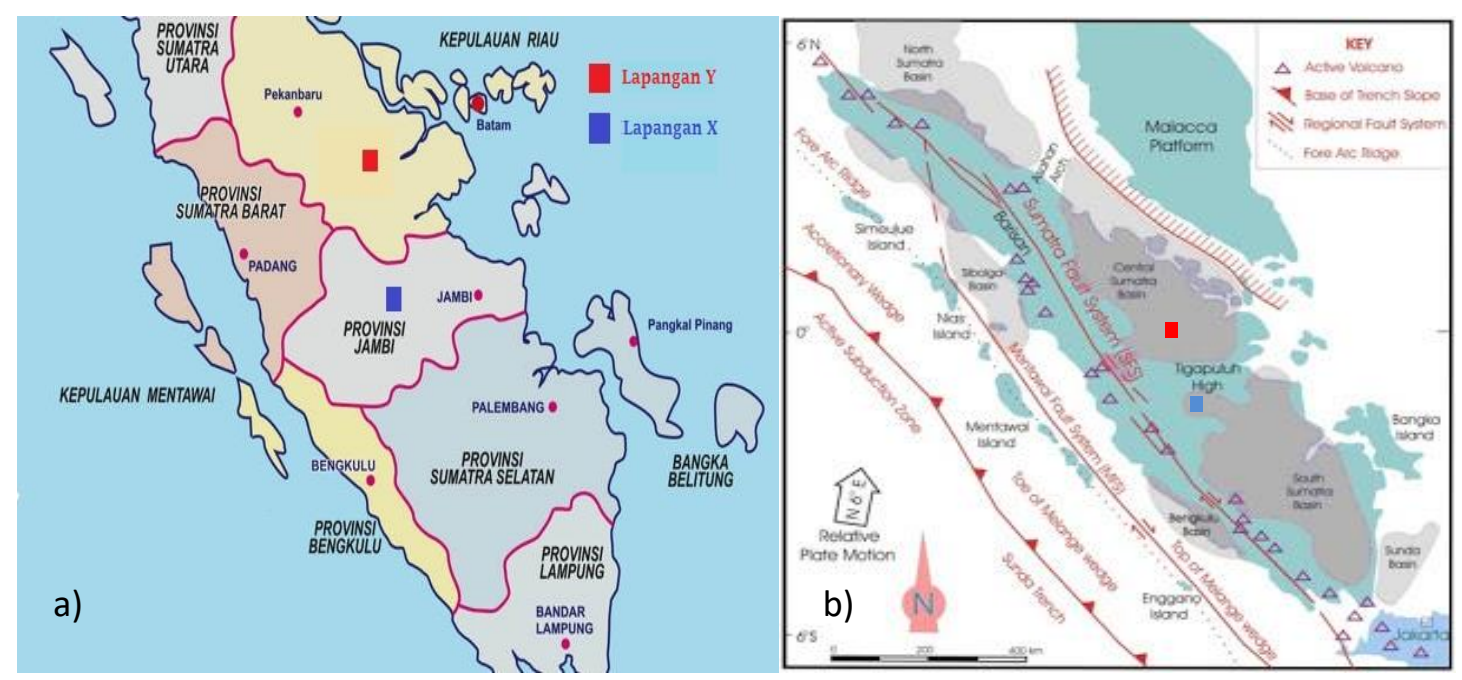

Gambar 1. Lokasi daerah penelitian: a) Lokasi administratif: lapangan X

(Provinsi Jambi) dan lapangan Y (Provinsi Riau) (Gambar dimodikasi dari wikipedia);

b) Lokasi berdasarkan cekungan sedimentasi, lapangan $X$ (Cekungan Sumatera Selatan) dan lapangan $Y$ (Cekungan Sumatera Tengah)

(Gambar dimodifikasi dari Darman and Sidi, 2000)

Lapangan $X$ di Kabupaten Tebo dan Kabupaten Batanghari, Provinsi Jambi, termasuk ke dalam Cekungan Sumatera Selatan, sedangkan Lapangan $Y$ terdapat di Kabupaten Pelalawan Provinsi Riau, termasuk ke dalam Cekungan Sumatera Tengah. Formasi pembawa batubara pada Lapangan $X$ adalah Formasi Muaraenim dan Formasi Kasai, sedangkan pada lapangan $Y$ adalah Formasi Petani.

Percontoh batubara yang digunakan dalam penelitian ini berasal dari hasil penyelidikan batubara yang dilakukan oleh Pusat Sumber Daya Mineral Batubara dan Panas Bumi (PSDMBP) tahun 2015. Proses karakterisasi dilakukan dengan melalui tahapan: pemercontohan (pengambilan percontoh batubara), analisis kimia berupa proksimat, ultimat, dan nilai kalori serta analisis fisik (analisis petrografi berupa analisis maseral dan reflektansi vitrinit/huminit).

\section{GEOLOGI}

Lapangan X berada pada Peta Geologi Lembar Muarabungo skala 1:250.000 (Simanjuntak dkk, 1994) terletak antara Cekungan Sumatera Selatan dan Cekungan Sumatera Tengah, namun sebagian besar wilayahnya termasuk ke dalam Cekungan Sumatera Selatan bagian utara atau subcekungan Jambi dan sebagian kecil termasuk ke dalam Cekungan Sumatera Tengah (Gambar 1b). Batubara pada lapangan $X$ termasuk ke dalam Formasi Muaraenim dan Formasi Kasai. Formasi Muaraenim yang berumur Miosen Akhir terbentuk sebagai akibat meningkatnya aktivitas vulkanik serta kemunculan Pegunungan Barisan ke arah barat sebagai sumber material sedimen. Litologi pencirinya berupa batulempung, batupasir, dan batulempung tufaan serta ditemukannya beberapa lapisan batubara. Formasi ini mencirikan lingkungan fluvial hingga transisi (Ginger dan Fielding, 2005). Formasi Kasai terendapkan pada Pliosen hingga Plistosen. Formasi ini terbentuk oleh proses susut laut dan pengangkatan. Litologi pencirinya merupakan tufa, batulanau, dan batuan vulkanoklastik dengan lingkungan penciri yaitu transisi hingga terrestrial.(De Coster, 1974).

Lapangan $Y$ merupakan bagian dari Cekungan Sumatera Tengah, salah satu dari tiga cekungan busur-belakang Sumatera (Sumatera/back arc basin) yang terbentuk selama Tersier Awal (Eosen Oligosen), terdiri atas rangkaian blok sembul (horst) dan terban (graben) yang terbentuk sebagai respon ekstensi busur 
belakang (Gambar 1b). Secara regional, Lapangan $Y$ termasuk pada peta geologi Lembar Pekanbaru (Clarke dkk., 1982). Formasi Petani diendapkan pada Miosen Tengah - Plistosen dalam lingkungan laut yang berubah menjadi lingkungan payau hingga darat. Formasi ini tersusun atas batulumpur yang mengandung lignit, batulempung karbonan dan interkalasi batupasir batulanau, yang ke arah atas menunjukkan terjadinya pendangkalan lingkungan pengendapan dan adanya pengurangan pengaruh laut (Clarke dkk, 1982; De Coster, 1974).

\section{METODOLOGI}

Penelitian ini menggunakan enam percontoh batubara lapangan $X$ dan delapan percontoh batubara lapangan $Y$. Semua percontoh diambil dari singkapan batubara yang ditemukan di permukaan. Seluruh percontoh batubara dianalisis di laboratorium secara fisika dan kimia. Analisis fisik berupa petrografi batubara yang meliputi analisis nilai reflektansi vitrinit/huminit dan analisis komposisi maseral. Analisis kimia meliputi analisis ultimat dan proksimat. Analisis proksimat dilakukan untuk menentukan kandungan kelembaban (moisture/M), Abu(Ash)), zat terbang (volatile matterNM) dan karbon tertambat (fixed carbon/FC). Sementara itu, analisis ultimat dilakukan untuk mengetahui kandungan unsur karbon (C), hidrogen $(H)$, oksigen $(O)$, nitrogen $(N)$, dan sulfur (S) dalam percontoh batubara yang dianalisis.

Analisis reflektansi vitrinit/huminit (Rv) dilakukan dengan menggunakan mikroskop polarisasi dengan tambahan minyak imersi. Percontoh batubara dipersiapkan dalam bentuk polished block, dengan pertimbangan bahwa batubara yang dianalisis adalah batubara peringkat rendah. Sebagai standar kalibrasi indeks reflektansi, digunakan Spinel dan YAG (ylidium, alumunium, garnet) dengan nilai reflektansi masing-masing 0,426 dan
0,892 . Pengukuran reflektansi vitrinit dilakukan dengan mengacu pada International Organization for Standardization nomor 7404-5:1994, yaitu sebanyak 100 kali pada tiap percontoh polished block batubara, dengan standar deviasi kurang dari $0,05 \%$. Analisis komposisi maseral menggunakan mikroskop Carl Zeiss/ J\&M/ HB0100 tipe Axioplan 2/PMT III dengan sinar flouresen, sinar pantul dan kamera tambahan. Perhitungan komposisi maseral pada setiap polished block batubara dilakukan pada 500 titik. Dalam penelitian ini, klasifikasi maseral yang digunakan adalah klasifikasi maseral batubara peringkat rendah yang diterbitkan oleh (International Committee for Coal and Organic Petrology (ICCP) 1994 (ICCP, 2001; Pickel dkk, 2017; Sykorova, dkk 2005). Dalam klasifikasi ini penamaan maseral vitrinit untuk batubara peringkat rendah $(<0,4 \%)$ adalah huminit.

Untuk mendukung hasil analisis petrografi batubara, persamaan Parr (Parr, 1928) digunakan untuk menentukan kandungan mineral matter berdasarkan kandungan abu (A) dan sulfur (S) dalam air-dried basis (adb) percontoh batubara yang dianalisis yaitu:

$$
\text { Mineral matter }(\% \mathrm{w} / \mathrm{w})=1.8 \mathrm{~A}+0.55 \mathrm{~S}
$$

sedangkan dalam penentuan lingkungan pengendapan, penelitian ini menggunakan formula Diessel (1992) berupa Tissue Preservation Index (TPI) dan Gelification Index (GI) yang telah dimodikasi oleh Amijaya dan Littke (2005) untuk batubara peringkat rendah, yaitu:

$$
\mathrm{TPI}=\text { (telohuminit }+ \text { teloinertinit) }
$$

(humodetrinit + humocollinit + inertodetrinit + geloinertinit)

$$
\mathrm{GI}=\frac{\text { (huminit }+ \text { geloinertinit) }}{\text { (inertinit) }}
$$

Hasil perhitungan TPI dan GI kemudian diplot ke dalam diagram lingkungan pengendapan Diessel. 


\section{HASIL DAN PEMBAHASAN}

\section{Hasil Analisis kimia}

Hasil analisis proksimat, ultimat, kalori, dan hasil perhitungan persamaan Parr dapat dilihat pada Tabel 1. Pada lapangan $X$, percontoh yang dianalisis pada umumnya menunjukkan karakteristik yang sama (Gambar 2). Hanya percontoh SJ2 yang menunjukkan anomali. Percontoh tersebut memiliki kandungan abu yang sangat tinggi dan memiliki nilai VM, FC, C serta nilai kalori yang lebih rendah jika dibandingkan dengan percontoh lainnya (Tabel 2 dan Gambar 2). Berdasarkan karakteristiknya, disimpulkan bahwa percontoh SJ2 bukan batubara melainkan batulempung karbonan. Tanpa percontoh SJ2, kandungan abu batubara lapangan $X$ relatif rendah (rata-rata 5\%). Nilai VM batubara lapangan $X$ berada pada rentang $44 \%$ s.d. $51 \%$ dengan nilai rata-rata $41,6 \%$. Sementara itu nilai FC berkisar antara $34 \%$ s.d. $44 \%$ dengan nilai rata-rata $33 \%$.

Pada lapangan $Y$, seluruh batubara yang dianalisis menunjukkan karakteristik yang lebih homogen (Gambar 3). Nilai FC batubara lapangan $Y$ berada pada rentang $34 \%$ s.d. $41 \%$ dengan nilai rata-rata $38 \%$, sedangkan nilai VM berada pada rentang $41 \%$ s.d. $51 \%$ dengan nilai rata-rata $47 \%$. Batubara lapangan $\mathrm{Y}$ memiliki nilai ratarata VM dan FC yang relatif lebih tinggi daripada batubara lapangan $X$. Kandungan abu dan sulfur batubara lapangan $Y$ juga relatif lebih tinggi daripada batubara lapangan X (Tabel 1 dan Gambar 2).

Tabel 1. Hasil analisis kimia batubara Lapangan $X$ dan $Y$

\begin{tabular}{|c|c|c|c|c|c|c|c|c|c|c|c|c|c|}
\hline \multirow{2}{*}{ Daerah } & \multirow{2}{*}{$\begin{array}{c}\text { Kode } \\
\text { Percontoh }\end{array}$} & \multirow{2}{*}{ Litologi } & \multicolumn{4}{|c|}{$\begin{array}{c}\text { Analisis proksimat } \\
\text { (\% adb) }\end{array}$} & \multicolumn{5}{|c|}{ Analisis Ultimat (\% daf) } & \multirow{2}{*}{$\begin{array}{c}\text { Nilai Kalori } \\
\text { (kkal/kg } \\
\text { adb) }\end{array}$} & \multirow{2}{*}{$\begin{array}{c}\text { Kandungan } \\
\text { mineral Rumus } \\
\text { Parr (\%) }\end{array}$} \\
\hline & & & M & Abu & FC & VM & C & $\mathbf{H}$ & 0 & $\mathbf{N}$ & $\mathbf{s}$ & & \\
\hline \multirow{6}{*}{$x$} & TA2 & Batubara & 6,57 & 1,42 & 43,95 & 48,07 & 68,64 & 4,99 & 24,78 & 1,25 & 0,34 & 6010 & 2,74 \\
\hline & TA5 & Batubara & 7,53 & 14,28 & 34,35 & 43,85 & 65,43 & 5,24 & 27,90 & 1,04 & 0,40 & 4883 & 25,93 \\
\hline & TA6 & Batubara & 7,60 & 8,90 & 38,97 & 44,54 & 67,15 & 5,20 & 26,39 & 0,96 & 0,31 & 5353 & 16,19 \\
\hline & SJ1 & Batubara & 8,98 & 2,28 & 37,87 & 50,88 & 66,76 & 5,25 & 27,21 & 0,42 & 0,36 & 5689 & 4,30 \\
\hline & SJ2 & Lempung $\mathrm{K}$, & 4,08 & 75,16 & 5,11 & 15,06 & 46,75 & 8,32 & 42,30 & 1,47 & 1,16 & 906 & 135,93 \\
\hline & SJ3 & Batubara & 9,09 & 2,94 & 40,38 & 47,60 & 67,39 & 5,01 & 26,39 & 0,95 & 0,26 & 5636 & 5,44 \\
\hline \multirow{9}{*}{$\mathrm{Y}$} & SGT03 & Batubara & 7,71 & 16,15 & 35,16 & 41,00 & 64,77 & 5,13 & 27,06 & 0,98 & 2,05 & 4767 & 30,02 \\
\hline & SGT05 & Batubara & 7,81 & 6,32 & 38,16 & 47,72 & 67,01 & 5,26 & 26,24 & 1,00 & 0,49 & 5530 & 11,65 \\
\hline & SGT06A & Batubara & 7,10 & 6,03 & 37,29 & 49,59 & 65,40 & 5,17 & 27,64 & 1,02 & 0,77 & 5518 & 11,28 \\
\hline & SGT06B & Batubara & 7,36 & 2,33 & 39,40 & 50,92 & 67,67 & 5,18 & 25,98 & 0,90 & 0,28 & 5787 & 4,35 \\
\hline & SGT07 & Batubara & 8,13 & 6,08 & 36,64 & 49,15 & 65,42 & 4,98 & 28,22 & 1,10 & 0,28 & 5227 & 11,10 \\
\hline & SGT08A & Batubara & 6,60 & 18,85 & 34,05 & 45,52 & 66,14 & 5,43 & 26,77 & 1,01 & 0,66 & 5070 & 34,30 \\
\hline & SGT08B & Batubara & 7,71 & 3,59 & 40,85 & 47,85 & 66,91 & 5,00 & 26,91 & 0,78 & 0,41 & 5626 & 6,69 \\
\hline & KUAR & Batubara & 6,88 & 8,12 & 40,67 & 44,34 & 67,35 & 5,09 & 24,22 & 1,18 & 2,15 & 5504 & 15,80 \\
\hline & PKG01 & Batubara & 8,21 & 3,80 & 40,21 & 47,79 & 65,91 & 4,93 & 27,50 & 1,09 & 0,57 & 5447 & 7,15 \\
\hline
\end{tabular}

$\mathrm{adb}=$ air dried basis, daf $=$ dry ash free basis, Lempung $\mathrm{K}=$ Lempung karbonan 


\section{MAKALAH ILMIAH}

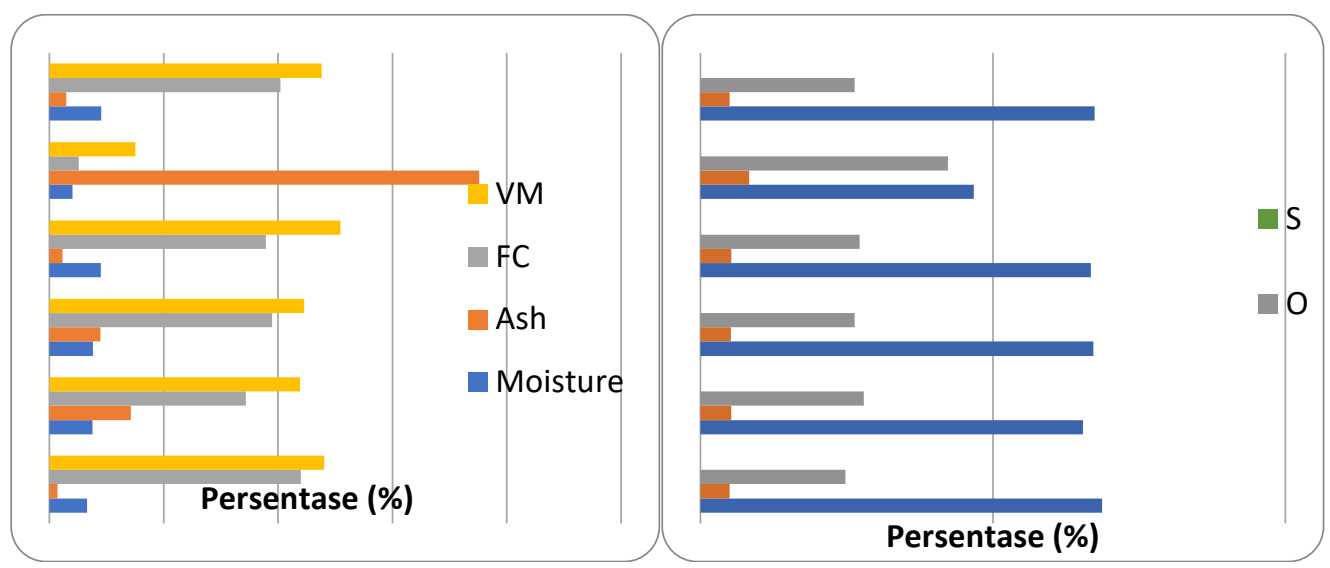

Gambar 2. Karakteristik batubara lapangan $X$

berdasarkan hasil analisis proksimat dan ultimat

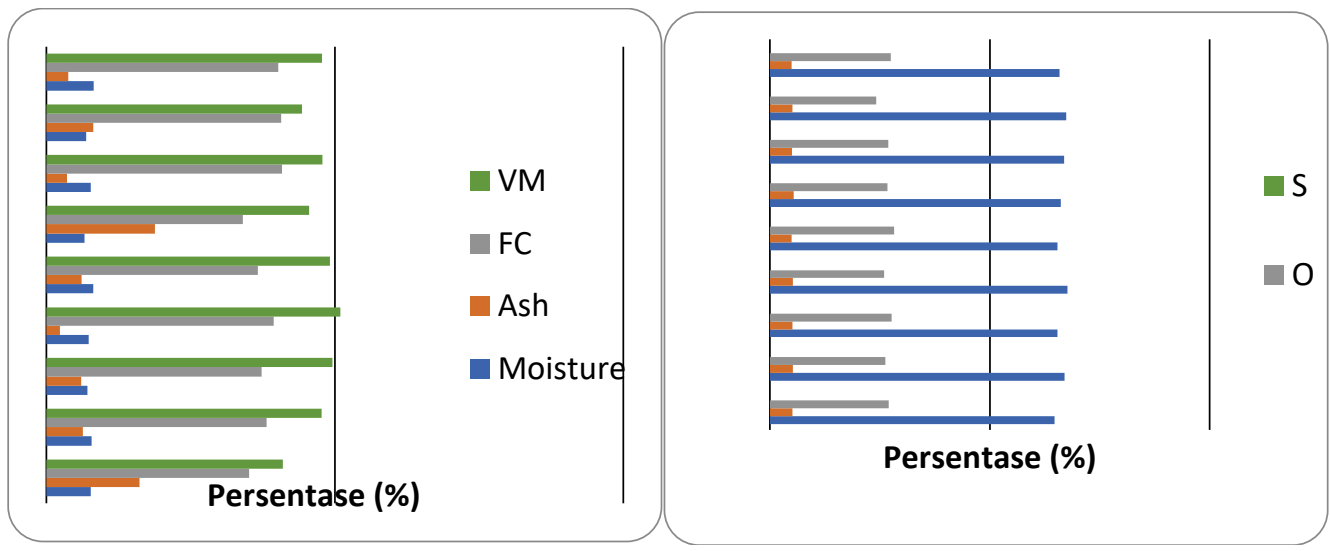

Gambar 3. Karakteristik batubara lapangan $Y$

berdasarkan hasil analisis proksimat dan ultimat

\section{Hasil Analisis Petrografi}

Hasil analisis reflektansi huminit (Rv) menunjukkan bahwa nilai reflektansi batubara lapangan $X$ dan $Y$ berada pada kisaran 0,24\% s.d. 0,37\% (Tabel 2). Tanpa percontoh SJ2, batubara lapangan $\mathrm{X}$ memiliki nilai Rv rata-rata $0,27 \%$, sedangkan batubara lapangan $Y$ memiliki nilai Rv rata-rata 0,29\% (Tabel 2).

Kandungan huminit batubara lapangan $X$ berada pada kisaran $66 \%$ s.d. $89 \%$, kandungan liptinit berada pada rentang $1 \%$ s.d. $10 \%$, sedangkan inertinit $1 \%$ s.d. $14 \%$ (Tabel 3). Batubara lapangan $Y$ memiliki kandungan huminit sedikit lebih tinggi daripada lapangan $X$ pada rentang $76 \%$ s.d. $94 \%$, kandungan liptinit pada kisaran $0,4 \%$ s.d. $2 \%$ serta intertinit $1 \%$ s.d. $8 \%$ (Gambar 4). Huminit pada batubara lapangan $X$ lebih didominasi oleh detrovitrinit, sementara pada lapangan $Y$ didominasi oleh telohuminit (Gambar 5). Hanya tiga jenis maseral Liptinit yang terdeteksi dengan alat point counter yaitu kutinit, suberinit dan resinit. Maseral lainnya yang terdeteksi tapi tidak terhitung dengan alat point counter adalah inertodetrinit. Sementara maseral inertinit batubara di kedua lapangan didominasi teloinertinit (semifusinit dan fusinit) dan detroinertinit (inertodetrinit). Secara umum, lapangan $X$ memiliki batubara dengan kandungan liptinit dan inertinit yang lebih tinggi daripada lapangan $Y$ (Gambar 4). Kandungan mineral matter batubara Lapangan $X$ juga sedikit lebih tinggi daripada lapangan $Y$ (Tabel 2). Mineral yang ditemukan sebagian besar berupa mineral lempung, pirit, dan sedikit oksida besi. Kenampakan maseral pada batubara lapangan $X$ dan $Y$ dapat dilihat pada Gambar 6 dan Gambar 7. 


\section{MAKALAH ILMIAH}

Tabel 2. Hasil analisis petrografi batubara kedua lapangan

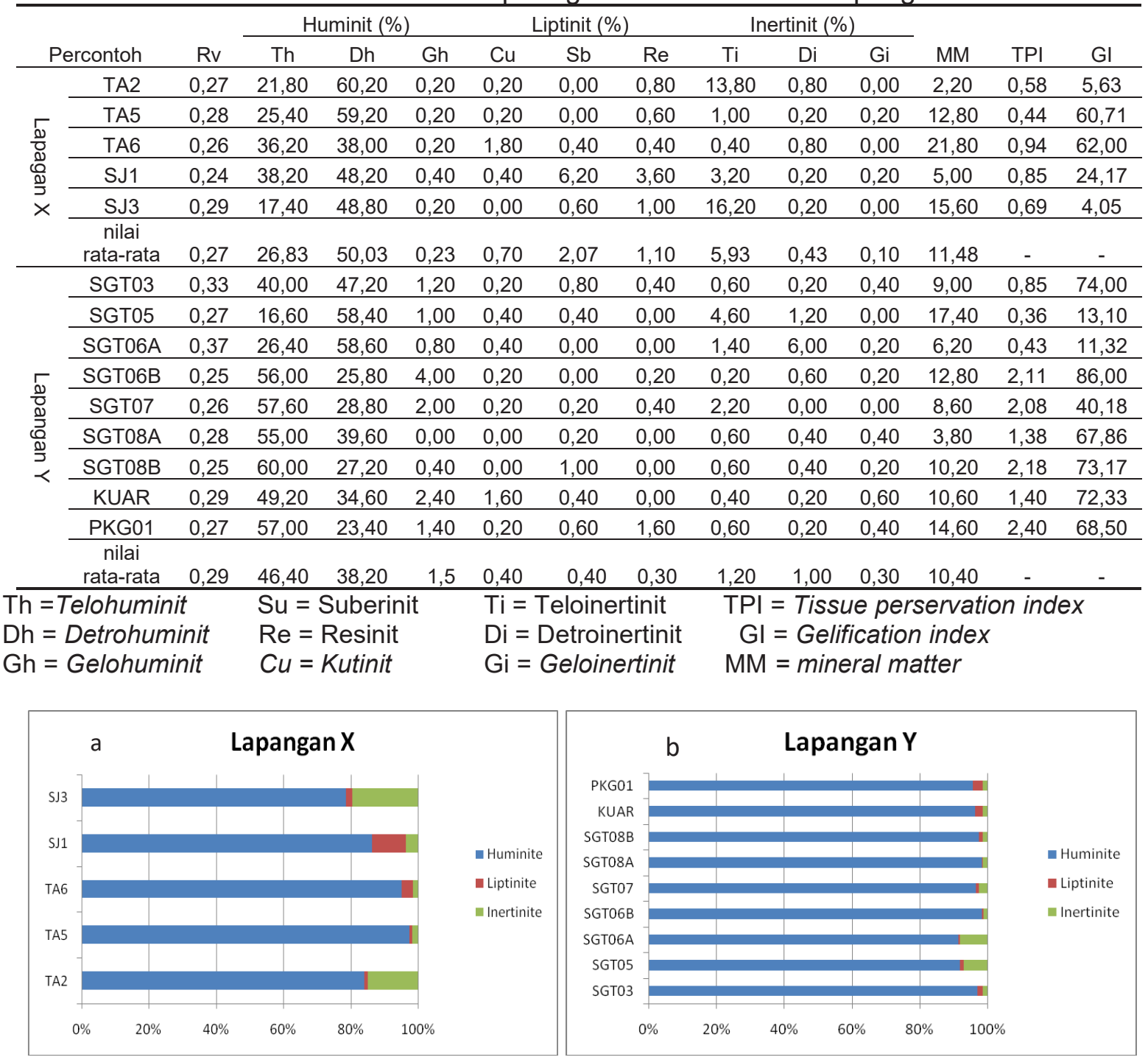

Gambar 4. Komposisi maseral batubara lapangan X (a) dan Y (b).

Huminit mendominasi maseral pada kedua lapangan.

Lapangan $\mathrm{Y}$ memiliki kandungan huminit yang lebih besar dari lapangan $\mathrm{X}$

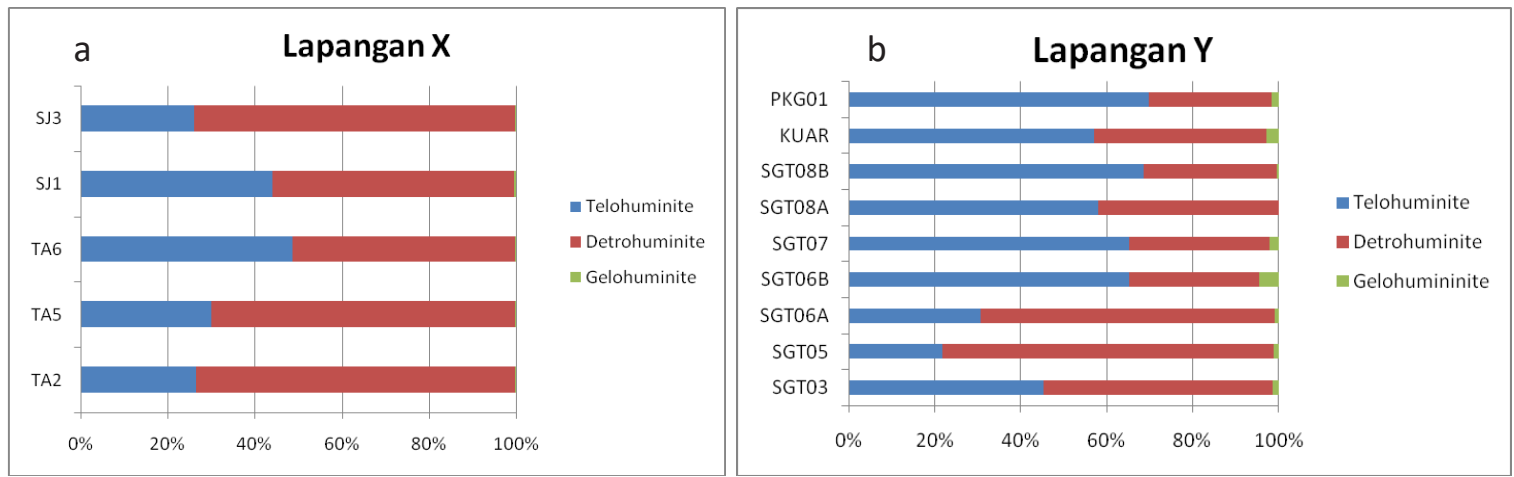

Gambar 5. Komposisi maseral huminit batubara lapangan $X(a)$ dan lapangan $Y(b)$. Maseral huminit pada lapangan $X$ didominasi detrohuminit sedangkan pada lapangan $Y$ didominasi telohuminit 


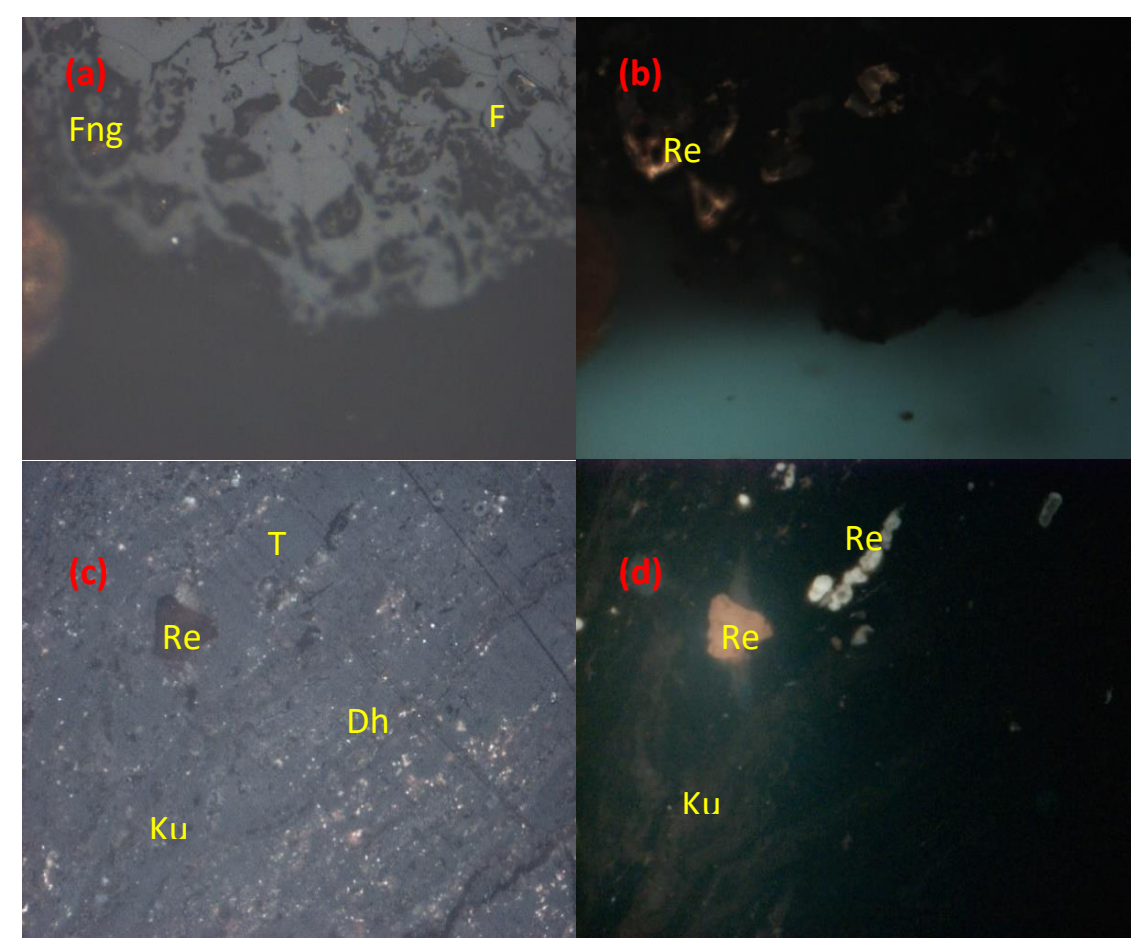

Gambar 6. Fotomikrografi maseral pada blok poles percontoh batubara lapangan $X$ (a) Maseral Funginit (Fng) dan Fusinit (Fu) (percontoh TA6; cahaya pantul putih); (b) Maseral Resinit $(\mathrm{Re})$ yang mengisi rongga maseral inertinit (percontoh TA6; cahaya fluoresen). (c) Telohuminit (Th), Detrohuminit (Dh) dan Resinit (Re) (percontoh SJ3; cahaya pantul putih); (d) Maseral Resinit (Re) dan kutinit (Ku) (percontoh SJ3; cahaya fluoresen)

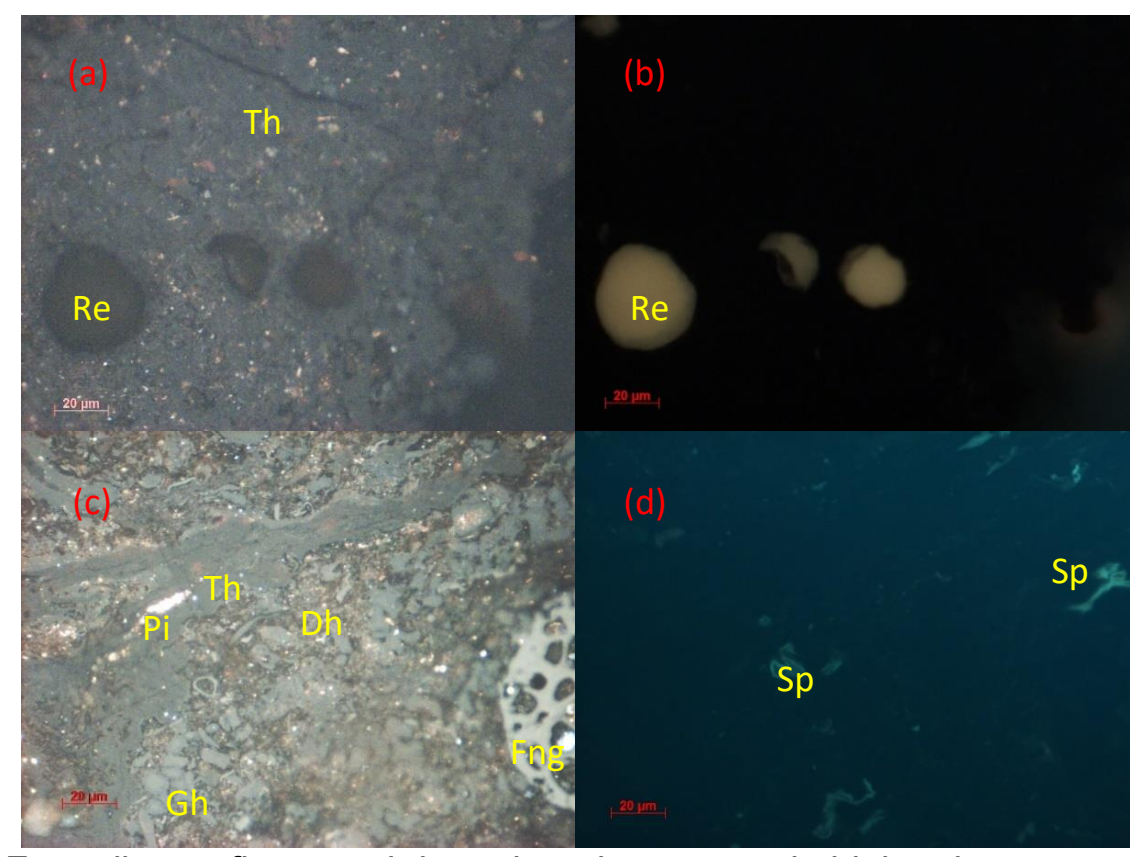

Gambar 7. Fotomikrografi maseral dan mineral matter pada blok poles percontoh batubara lapangan Y. (a). Maseral Telohuminit (Th) dan Resinit (Re) (percontoh KUAR; cahaya pantul putih); (b). Percontoh sama dengan (a) dalam cahaya fluoresen: maseral Resinit (Re); (c). Maseral Funginit (Fng), Telohuminit (Th),

Gelohuminit (Gh) dan Pirit (Pi) (percontoh SGT03; cahaya pantul putih); (d). Percontoh sama dengan (c) pada cahaya fluoresen: tampak maseral Sporinit (Sp) 


\section{PEMBAHASAN}

\section{Peringkat batubara}

Berdasarkan hasil analisis Rv, mengacu pada klasifikasi ASTM (1999) dan klasifikasi Diessel (1992) (Gambar 8) batubara Lapangan X (Rv rata-rata $0,27 \%$ ) dan batubara lapangan $\mathrm{Y}$ (Rv rata-rata $0,29 \%$ ) termasuk ke dalam peringkat batubara Lignit. Nilai Rv batubara Lapangan $Y$ sedikit lebih tinggi jika dibandingkan dengan batubara Lapangan $X$. Hal tersebut mengindikasikan bahwa pada saat proses pembatubaraan, batubara lapangan $Y$ kemungkinan mengalami pemaparan oleh suhu yang lebih tinggi atau tertimbun lebih dalam daripada batubara lapangan $\mathrm{X}$.

Untuk kepentingan pengklasifikasian batubara berdasarkan hasil analisis kimia, karena basis yang dipergunakan dalam klasifikasi ASTM adalah dry ash-free (daf), hasil analisis laboratorium dalam air-dried basis ( $a d b)$ terlebih dahulu dikonversikan ke dalam basis daf. Klasifikasi batubara berdasarkan hasil analisis kimia menunjukkan hasil yang berbeda jika dibandingkan dengan klasifikasi berdasarkan analisis fisika. Berdasarkan klasifikasi ASTM, percontoh batubara lapangan $X$ dan $Y$ yang memiliki nilai kalori berkisar antara 6.000 sampai $6.500 \mathrm{kkal} / \mathrm{kg}$ (daf) dan setara dengan $10.800 \mathrm{Btu} / \mathrm{lb}$ (daf) s.d. $11.700 \mathrm{Btu} / \mathrm{lb}$ (daf), termasuk pada kategori batubara subbituminus $A$ atau setara dengan Rv 0,47\%. Sementara itu apabila klasifikasi dilakukan berdasarkan pada kandungan VM (53\% s.d. $57 \%$, daf), batubara di kedua lapangan termasuk ke dalam kategori lignit hingga subbituminus (Gambar 8a). Jika menggunakan klasifikasi Diessel (1992) (Gambar 8.b), kandungan kalori batubara daerah penelitian yang berkisar antara 4.700 hingga $6.000 \mathrm{kkal} / \mathrm{Kg}$ (adb) atau setara dengan 19,8 $\mathrm{MJ} / \mathrm{J}$ hingga $25,5 \mathrm{MJ} / \mathrm{J}$ (gross specific energy) masih berada pada rentang batubara lignit. Dengan kata lain, klasifikasi Diessel cenderung lebih cocok untuk digunakan pada batubara daerah penelitian.

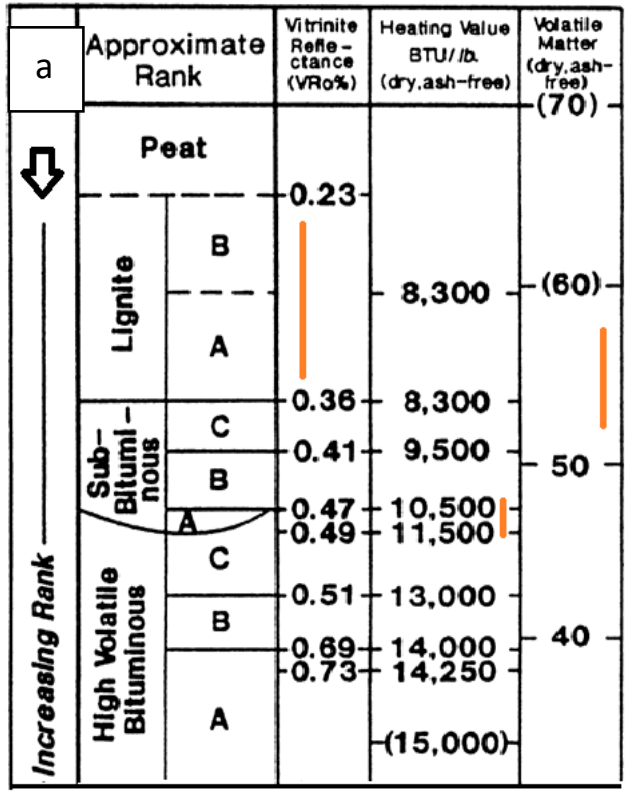

\begin{tabular}{|c|c|c|c|c|c|c|}
\hline \multirow[b]{3}{*}{ Rank Stage } & \multirow[b]{3}{*}{$\begin{array}{c}\text { \% Carbon } \\
\text { (daf) }\end{array}$} & \multirow[b]{3}{*}{$\begin{array}{c}\% \text { Volatile } \\
\text { Matter (daf) }\end{array}$} & \multirow{3}{*}{$\begin{array}{c}\text { Gross Specific } \\
\text { Energy } \\
(M / / \mathrm{kg})\end{array}$} & \multirow[b]{3}{*}{$\begin{array}{l}\% \text { in situ } \\
\text { Moisture }\end{array}$} & \multicolumn{2}{|c|}{$\%$ Vitrinite Reflectance } \\
\hline & & & & & $(0 i l, 546 \mathrm{~nm})$ & $\begin{array}{c}\text { (Diessel, } \\
\text { 1992a) }\end{array}$ \\
\hline & & & & & $R_{\text {tandom }}$ & $R_{\max }$ \\
\hline Wood & 50 & $>65$ & & & & \\
\hline Peat & 60 & $>60$ & 14.7 & 75 & 0.2 & 0.2 \\
\hline Lignite & 71 & 52 & 23 & 30 & 0.4 & 0.42 \\
\hline Subbituminous & 80 & 40 & 33.5 & 5 & 0.6 & 0.63 \\
\hline $\begin{array}{l}\text { High volatile } \\
\text { Bituminous }\end{array}$ & 86 & 31 & 35.6 & 3 & 097 & 1.03 \\
\hline $\begin{array}{l}\text { Medium volatile } \\
\text { Bituminous }\end{array}$ & 90 & 22 & 36 & $<1$ & 1.47 & 158 \\
\hline $\begin{array}{l}\text { Low volatile } \\
\text { Bituminous }\end{array}$ & 91 & 14 & 36.4 & 1 & 1.85 & 197 \\
\hline Semianthracite & 92 & 8 & 36 & 1 & 2.65 & 2.83 \\
\hline Anthracite & 95 & 2 & 35.2 & 2 & 6.55 & 7 \\
\hline
\end{tabular}

Gambar 8. Peringkat batubara kedua daerah penelitian (garis oranye) berdasarkan hasil analisis fisika (Rv) dan kimia (nilai kalori dan VM) mengacu pada: a) klasifikasi ASTM; dan b) klasifikasi Diessel (1992) 


\section{MAKALAH ILMIAH}

Lebih jauh, hasil analisis menunjukkan bahwa conto batubara dengan nilai Rv yang hampir sama ternyata memiliki nilai kalori yang berbeda (Gambar 9). Sebaliknya batubara dengan nilai Rv yang berbeda memiliki nilai kalori yang hampir sama (Gambar 9). Hal serupa juga terjadi ketika data Rv diplotkan terhadap data VM. Conto dengan nilai Rv yang hampir sama, memiliki kandungan VM yang berbeda dan conto dengan nilai $\mathrm{Rv}$ yang berbeda memiliki kandungan VM yang sama (Gambar 9). Hasil pengeplotan antara nilai Rv dan nilai kalori (Gambar 9a) serta pengeplotan nilai Rv dan VM (Gambar 9b) untuk semua conto batubara di Lapangan $X$ dan Lapangan $Y$ menunjukkan nilai koefisien korelasi $\left(R^{2}\right)<0,5$, sehingga disimpulkan bahwa di daerah penelitian nilai Rv tidak memiliki korelasi langsung dengan nilai kalori dan VM.

Nilai kalori adalah salah satu parameter yang paling banyak digunakan untuk menentukan kualitas batubara dalam dunia industri. Nilai kalori dalam batubara di samping ditentukan oleh peringkat pembatubaraan juga ditentukan oleh faktor lain, di antaranya oleh kandungan pengotor (mineral matter). Nilai kalori batubara cenderung menurun dengan meningkatnya kandungan mineral matter (Speight, 2013). VM adalah komponen dalam batubara yang dibebaskan pada temperatur tinggi dalam kondisi hampa udara, dan terdiri atas gas seperti hidrogen, $\mathrm{CO}, \mathrm{CH}_{4}, \mathrm{C}_{2} \mathrm{H}_{6}$ dan juga $\mathrm{CO}_{2}$. Nilai VM dipengaruhi oleh komposisi maseral batubara. Sebagai contoh, maseral liptinit lebih banyak menghasilkan VM daripada huminit dan inertinit. Selain komposisi maseral, hal lain yang juga mempengaruhi kandungan VM dalam batubara adalah kandungan mineral matter (Speight, 2013). Sebagai contoh, mineral karbonat akan melepaskan $\mathrm{CO}_{2}$, pirit akan melepaskan $\mathrm{S}$ atau pembentukan hidrogen klorida dari mineral klorida. Sementara nilai Rv cenderung lebih independen dan tidak terpengaruh komposisi maupun kandungan pengotor dalam batubara. Dalam hal ini perbedaan klasifikasi batubara berdasarkan analisis kimia dan fisika kemungkinan dipengaruhi baik oleh komposisi maseral maupun kandungan mineral yang ada dalam batubara di daerah penelitian.

Perlu diketahui untuk kepentingan penelitian, klasifikasi batubara yang biasa digunakan untuk menentukan peringkat batubara Indonesia, sebagian besar mengacu pada klasifikasi luar negeri (contoh: ASTM) yang kemungkinan tidak cocok untuk batubara Indonesia. Di Indonesia belum ada standar khusus yang mengklasifikasikan batubara Indonesia berdasarkan nilai $\mathrm{Rv}$ dan parameter peringkat lainnya. Saat ini pengklasifikasian batubara Indonesia berdasarkan peringkat lebih bersifat praktis untuk kepentingan dunia industri, yaitu batubara hanya diklasfikasikan berdasarkan nilai kalori (SNI 6728.4.2015).

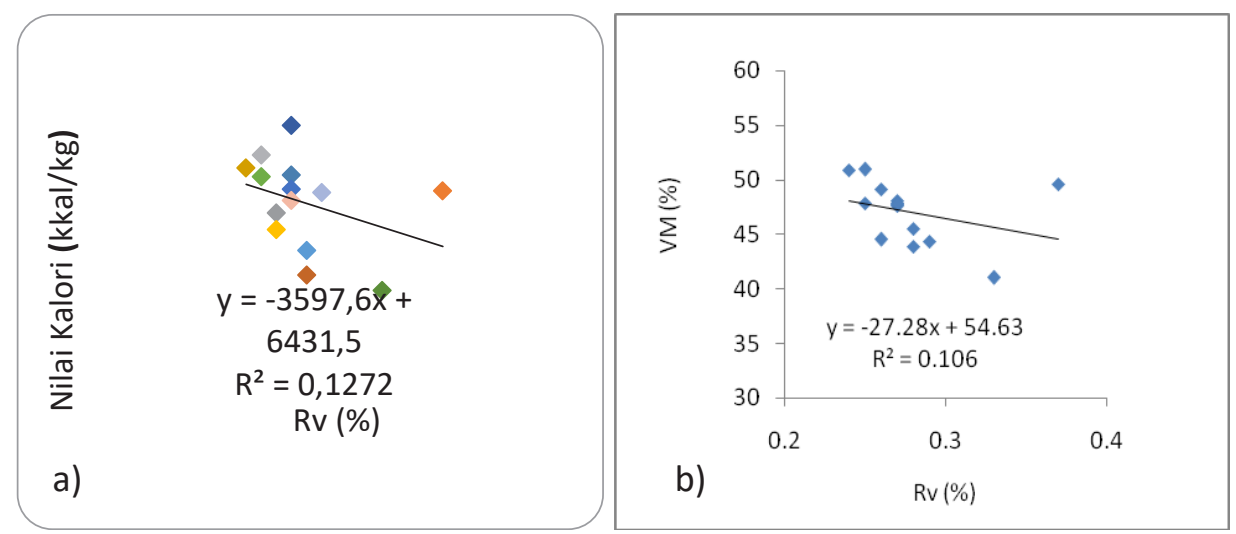

Gambar 9. Grafik korelasi regresi conto batubara Lapangan X dan lapanganY:

(a) Rv vs nilai kalori; (b) Rv vs Vm 
Menurut Speight (2013) batubara dari lokasi berbeda cenderung memiliki ciri yang juga berbeda, sehingga memerlukan perlakuan yang berbeda pula. Dalam hal ini, ada kemungkinan bahwa ketidaksesuaian antara hasil analisis kimia dan fisika dalam klasifikasi ASTM disebabkan oleh kisaran nilai kualitas batubara Indonesia yang tidak terangkum dalam kisaran nilai klasifikasi ASTM. Dalam hal ini dipandang perlu untuk membuat klasifikasi khusus untuk batubara Indonesia yang disesuaikan dengan karakteristik batubara Indonesia.

\section{Tipe Batubara}

Komposisi maseral hasil analisis petrografi diplot ke dalam diagram segitiga untuk mengetahui informasi pengendapan batubara (Gambar 10). Dari 6 conto batubara Lapangan $X$ hanya 5 conto yang diplotkan ke dalam diagram karena satu conto yaitu SJ2 memperlihatkan karakteristik bukan batubara, Hasil pengeplotan menunjukkan, bahwa batubara di daerah $\mathrm{X}$ dapat dibedakan ke dalam 3 fasies, sementara batubara Lapangan $Y$ lebih homogen dan dapat dikelompokkan hanya ke dalam satu fasies (Tabel 3).

Kandungan huminit yang tinggi merupakan ciri khas batubara Indonesia dan mengindikasikan bahwa material pembentuk batubara diendapkan sebagai gambut pada lingkungan hutan rawa basah yang berada pada kondisi anaerobik (Flores, 2002). Terbentuknya fasies II dan fasies III pada Lapangan $X$ dengan kandungan inertinit yang relatif tinggi yang sebagian besar berupa teloinertinit (dalam bentuk fusinit) mengindikasikan bahwa lingkungan pengendapan gambut pernah terbakar dan/atau gambut terpapar udara sehingga maseral teroksidasi dan mengalami dehidrasi (O'Keefe dkk, 2013). Kehadiran telohuminit yang terbentuk dari dinding sel tumbuhan berkayu, mengindikasikan bahwa proses pembusukan tumbuhan sebagian besar berlangsung pada kondisi anaerobik atau hanya sedikit mendapat pengaruh udara. Sementara itu kehadiran detrohuminit yang terbentuk dari sisa-sisa tumbuhan berkayu mengindikasikan bahwa proses pembusukan berlangsung signifikan pada kondisi aerobik (O'Keefe dkk, 2013). Banyaknya telohuminit pada batubara Lapangan $Y$ mengindikasikan bahwa material pembentuk batubara pada lapangan tersebut sedikit terpengaruh udara atau lebih banyak mengalami pembusukan dalam kondisi anaerobik (tanpa udara) dibanding batubara Lapangan X.

Tabel 3. Fasies Batubara Lapangan $X$ dan Lapangan $Y$

\begin{tabular}{ll} 
Lapangan $\mathbf{X}$ & Lapangan $Y$ \\
\hline Fasies 1: $\mathrm{H}>90 \% ; \mathrm{L}<10 \%, \mathrm{I}<10 \%$ & Fasies $1 ; \mathrm{H}>90 \% ; \mathrm{L}<10 \% ; \mathrm{I}<10 \%$ \\
\hline Fasies 2: $\mathrm{H} 80 \%$ s.d. $90 \% ; \mathrm{L} 10 \% ; \mathrm{I} 10 \%$ s.d. $15 \%$ & \\
\hline Fasies 3: $\mathrm{H} 75 \%$ s.d. $85 \% ; \mathrm{L}<10 \% ; \mathrm{I} 15 \%$ s.d. $20 \%$ & \\
\hline
\end{tabular}

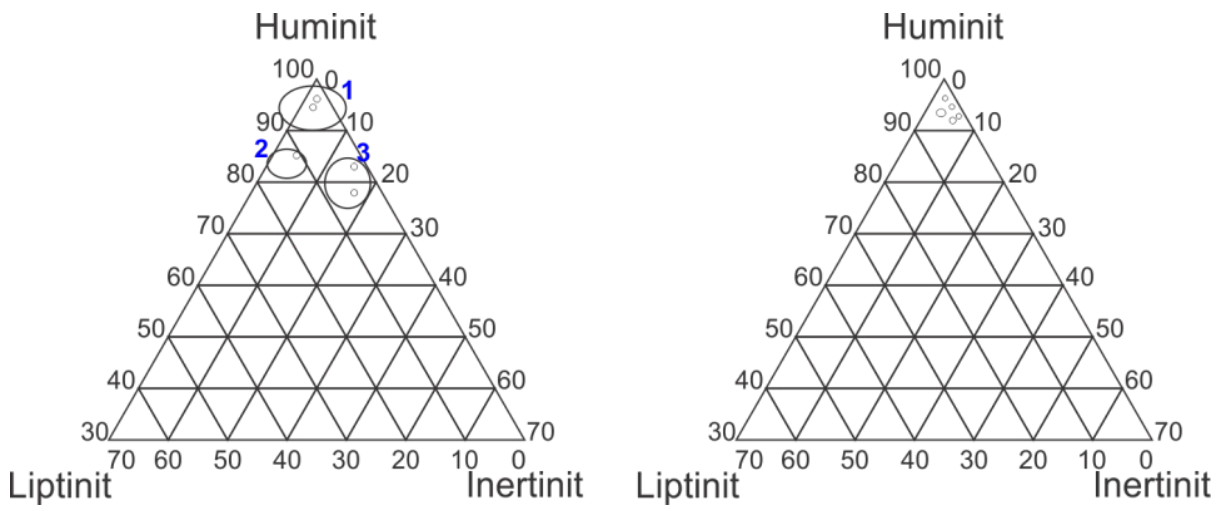

Gambar 10. Diagram segitiga komposisi maseral Lapangan $X$ (kiri) dan Lapangan $Y$ (kanan) 
Hasil perhitungan TPI dan GI serta pengeplotan nilai tersebut ke dalam Diagram Diessel, menunjukkan bahwa kedua lapangan memiliki kondisi yang berbeda. Secara umum, Lapangan $X$ dicirikan oleh lingkungan dominasi limnicmarsh, sementara Lapangan $\mathrm{Y}$ oleh telmatic (Gambar 11).

Batubara Lapangan $X$ memiliki indeks $\mathrm{Gl}$ medium (1-10) hingga tinggi $(>10)$ dan indeks TPI yang rendah (<1) (Gambar 11). Nilai TPI yang rendah untuk Batubara Miosen di Sumatera kemungkinan disebabkan karena bagian tengah dari kubah gambut di Indonesia disusun oleh hutan tumbuhan tingkat rendah dengan ketinggian $1 \mathrm{~m}$ yang lebih mudah membusuk dibandingkan tumbuhan berkayu yang mencapai ketinggian $40 \mathrm{~m}$ sampai $50 \mathrm{~m}$ (Anderson, 1983). Bahan selulosa dari tumbuhan herbaceous juga lebih mudah membusuk daripada bahan berkayu yang kaya akan lignin, sehingga nilai TPI rendah juga mengindikasikan bahwa mire didominansi oleh tumbuhan herbaceous atau bisa juga mengindikasikan terjadinya penghancuran tumbuhan berkayu dalam skala besar yang disebabkan oleh humifikasi ekstensif dan mineralisasi (Diessel, 1992). Nilai GI yang tinggi dan nilai TPI yang rendah serta kandungan abu dan mineral matter yang juga rendah mengindikasikan bahwa material pembentuk batubara di Lapangan $X$ adalah tumbuhan herbaceous yang diendapkan pada raised bog dalam kondisi basah yang terus menerus. Nilai GI yang tinggi adalah khas endapan batubara dan gambut di Indonesia (Amidjaja dan Littke, 2005).

Lebih jauh, diagram juga menunjukkan bahwa batubara Lapangan $X$ diendapkan pada lingkungan limnic-marsh dengan beberapa conto menunjukkan lingkungan limno-telmatic, Lingkungan limnic merupakan lingkungan perairan darat tanpa adanya hubungan air langsung ke laut (Diessel 1992). Marsh merupakan lingkungan rawa jauh dari laut dengan kondisi air dari sungai terperangkap oleh kelokan, percabangan atau perubahan muka air sungai dan hanya fluktuasi muka air laut yang tinggi saja yang memengaruhi lingkungan seperti marsh (Diessel 1992). Batubara Lapangan $X$ termasuk pada Formasi Muaraenim dan Formasi Kasai. Berdasarkan Ginger dan Fielding (2005). Formasi Muaraenim terbentuk pada lingkungan fluviatil, delta hingga pinggir pantai, sementara Formasi Kasai terbentuk pada lingkungan darat (terrestrial) hingga transisi. Secara umum, hasil analisis lingkungan pengendapan batubara $X$ dalam penelitian ini, yang menunjukkan lingkungan limnic (fluviatil), dan marsh (transisi) sesuai dengan lingkungan pengendapan Formasi Muaraenim dan Formasi Kasai yang diperoleh dari literatur (Amidjaja dan Litke, 2005; De Coster, 1974).

Untuk Lapangan $\mathrm{Y}$, hasil pengeplotan mengindikasikan bahwa conto batubara diendapkan pada lingkungan pengendapan yang berbeda-beda (Gambar 10). Conto SGT05 dan SGT06A menunjukkan lingkungan limnic-marsh, sedangkan conto SGT03, KUAR dan SGT08A terendapkan pada kondisi mendekati laut (limnotelmatic, lower delta plain). Sementara itu conto SGT06B, SGT08B, SGT07, dan PKG01 menunjukkan lingkungan telmatic. Sebagian besar batubara Lapangan $Y$ memiliki indeks TPI dan GI yang tinggi dengan kandungan abu yang rendah. Hal tersebut mengindikasikan, bahwa material asal pembentuk batubara diendapkan pada raised bog dalam kondisi terus-menerus basah (Diessel, 1992).

Conto batubara Lapangan $Y$ berasal dari Formasi Petani yang terbentuk pada lingkungan laut dangkal hingga darat mengindikasikan proses regresi (Clarke, 1982; De Coster, 1974). Dalam penelitian ini, hasil analisis fasies memberikan indikasi, bahwa lingkungan pengendapan batubara Lapangan $Y$ terpengaruh proses transgresi dan regresi muka air laut, yang ditunjukkan oleh dua conto pada lingkungan limnic yang tidak terhubung dengan laut, tiga conto menunjukkan lingkungan limno-telmatic yang mulai terhubung dengan laut dan empat conto 
menunjukkan lingkungan telmatic yang dipengaruhi oleh pasang surut muka air laut. Kandungan sulfur dan kandungan pirit batubara Lapangan $Y$ secara umum juga lebih tinggi daripada batubara Lapangan $\mathrm{X}$, sehingga mendukung interpretasi bahwa batubara Lapangan Y mendapat pengaruh air laut yang lebih besar daripada Lapangan $\mathrm{X}$.

\section{Mutu Batubara}

Mutu batubara (grade) merefleksikan bagaimana suatu batubara tetap terbebas dari pengaruh material anorganik baik selama penimbunan/pembebanan, sebelum penimbunan/pembebanan dan selama proses pembatubaraan yang ditunjukkan oleh rendahnya kandungan mineral matter dan tingginya kandungan material organik (Suarez dan Crelling, 2008). Secara sederhana, pembahasan mutu batubara dalam penelitian ini akan difokuskan pada pembahasan kandungan mineral matter conto batubara di kedua daerah penelitian.
Kandungan mineral matter dapat diketahui dengan menggunakan analisis petrografi atau melalui persamaan Parr (1928) dengan menggunakan parameter kimia. Mutu batubara kedua lapangan menunjukkan hasil yang serupa dengan kandungan mineral matter yang relatif rendah kecuali beberapa conto (Tabel 2 dan Tabel 3). Gambar 12 menunjukkan perbandingan kandungan mineral matter berdasarkan hasil analisis petrografi dan persamaan Parr. Hasil perhitungan dengan menggunakan persamaan Parr dengan hasil analisis petrografi sebagian besar tidak jauh berbeda. Perbedaan signifikan ditemukan pada conto batubara SGT03 dan SGT08B dari Lapangan Y. Adanya perbedaan yang cukup besar antara hasil analisis petrografi dan kimia kemungkinan disebabkan karena pada analisis petrografi, perhitungan persentase komposisi dilakukan berdasarkan pada titik tempat alat point-counter jatuh, sehingga beberapa individu mineral matter maupun maseral kemungkinan tidak termasuk ke dalam perhitungan.

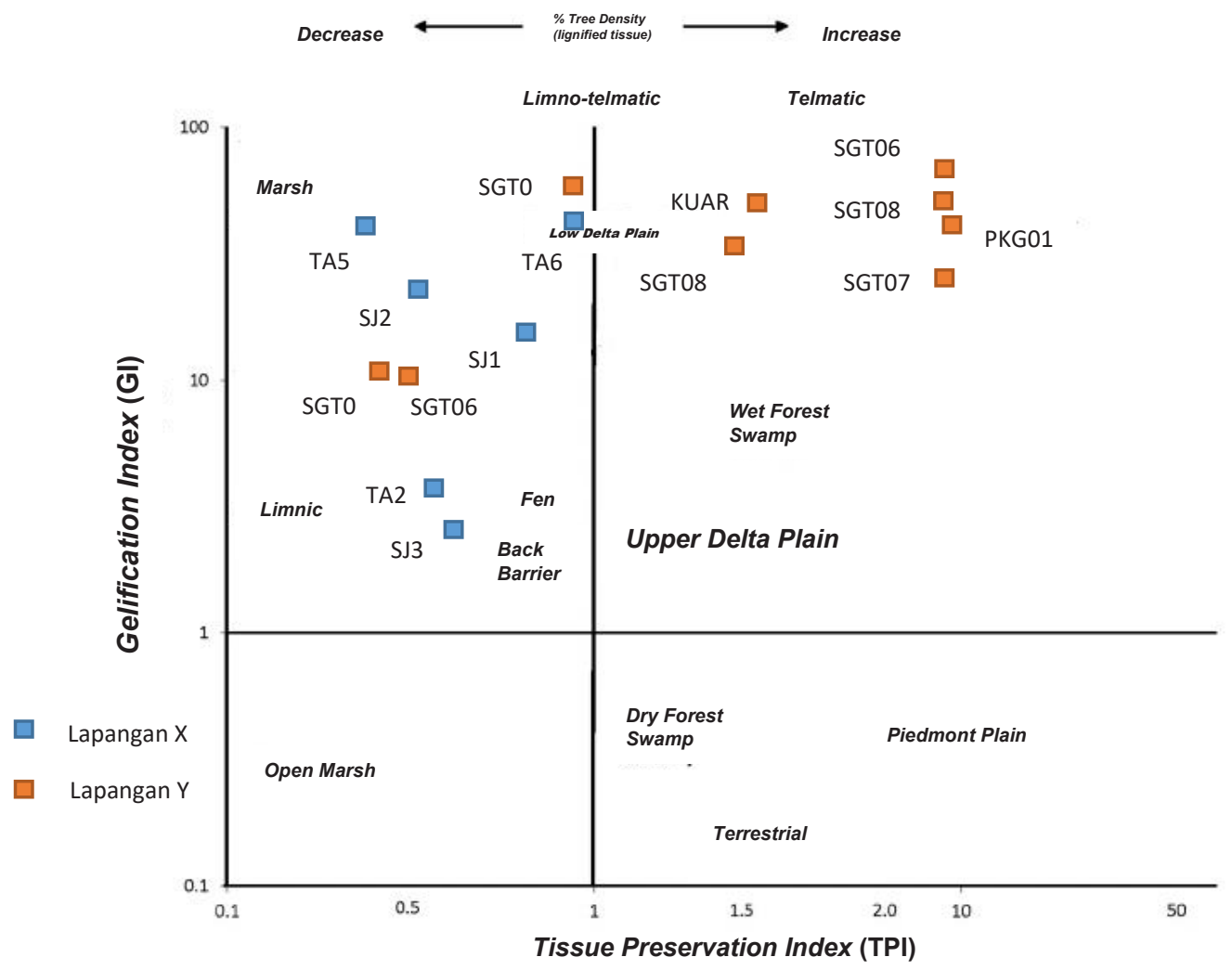

Gambar 11. Plot nilai TPI dan GI Lapangan X dan Lapangan Y pada Diagram Diessel 


\section{MAKALAH ILMIAH}

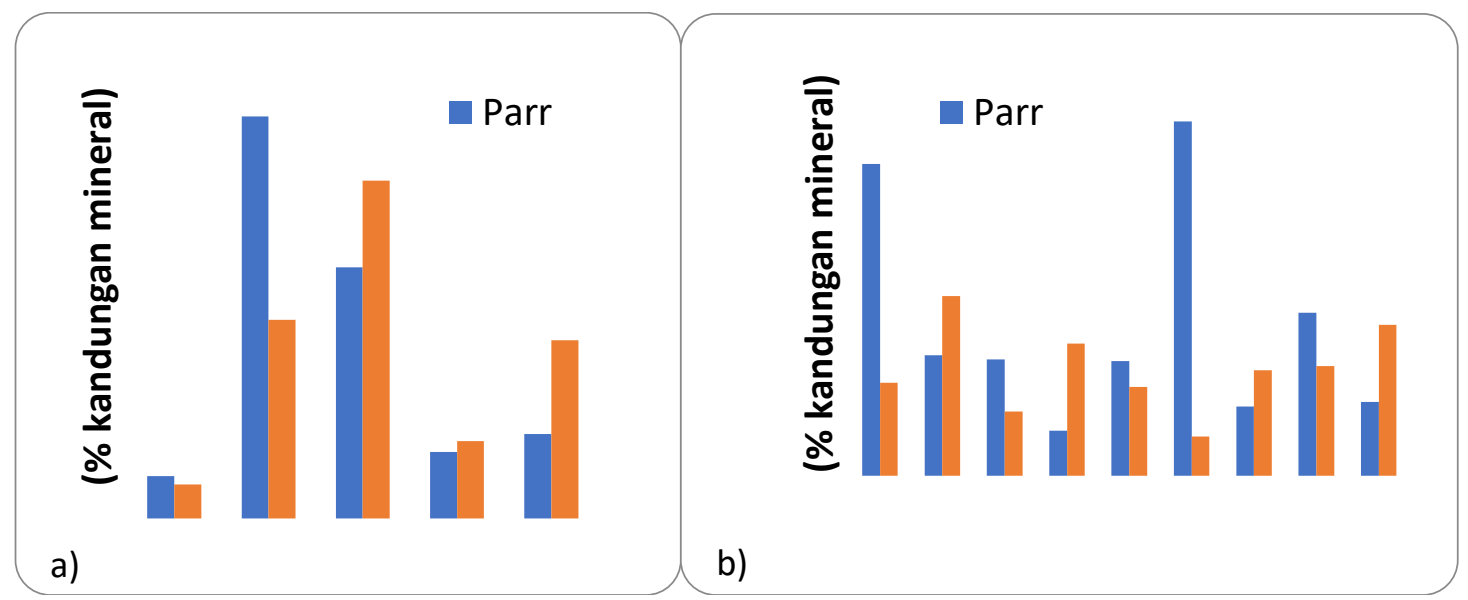

Gambar 12. Grafik perbandingan mineral matter pada batubara hasil persamaan Parr dengan analisis petrografi: a) Lapangan $X$ tanpa conto SJ2; b) Lapangan $Y$

Mineral matter sangat berpengaruh pada bagaimana batubara diproses, baik dalam hal penambangan, transportasi maupun bentuk penggunaannya. Ketika batubara dipanaskan pada unit pembakaran, kandungan mineral matter yang tinggi dapat mengakibatkan kerusakan pada tanur, banyaknya abu terbang, korosi maupun penyumbatan (Speight, 2013). Secara umum kandungan mineral matter batubara Lapangan $X$ dan Lapangan $Y$ relatif rendah (rata-rata $<10 \%$ ), sehingga menguntungkan dalam proses penggunaannya. Kandungan mineral matter yang rendah juga merupakan karakteristik batubara Indonesia yang diendapkan dalam lingkungan raised bog.

\section{KESIMPULAN}

Secara umum terdapat perbedaan karakteristik batubara Lapangan $X$ dan Lapangan $Y$ yang mengindikasikan bahwa kedua lapangan memiliki sejarah pengendapan yang berbeda. Hal tersebut sesuai dengan kondisi kedua lapangan yang memang berasal dari dua cekungan batubara yang berbeda. yaitu Cekungan Sumatera Tengah dan Cekungan Sumatera Selatan.

Batubara di kedua lapangan termasuk batubara peringkat rendah (lignit), hanya saja batubara Lapangan $\mathrm{Y}$ memiliki nilai reflektansi vitrinit yang sedikit lebih tinggi dibanding batubara Lapangan X. Hal ini mengindikasikan bahwa Lapangan $Y$ kemungkinan mendapatkan pengaruh temperatur dan tekanan yang lebih besar daripada batubara di Lapangan X.

Dalam penentuan peringkat batubara, terdapat perbedaan antara hasil analisis kimia (nilai kalori dan VM) dan hasil analisis fisika (reflektansi vitrinit). Dengan menggunakan klasifikasi ASTM, nilai reflektansi batubara di kedua lapangan menunjukkan peringkat lignit. Sementara itu berdasarkan nilai kalori termasuk Subbituminus $A$, dan berdasarkan VM termasuk lignit-subbituminus. Perbedaan tersebut diperkirakan merupakan ciri unik batubara Indonesia. Klasifikasi ASTM adalah klasifikasi untuk batubara luar negeri yang kemungkinan tidak cocok dipergunakan untuk batubara Indonesia, sehingga dibutuhkan klasifikasi khusus yang dibangun berdasarkan karakteristik batubara Indonesia.

Komposisi maseral batubara di kedua lapangan menunjukkan karakteristik yang berbeda. Terdapat tiga fasies batubara pada Lapangan $X$, sementara pada Lapangan $Y$ batubara lebih homogen dan hanya terdiri dari satu fasies. Kandungan kelompok huminit pada batubara Lapangan $X$ lebih didominasi oleh detrohuminit sementara Lapangan $\mathrm{Y}$ didominasi oleh telohuminit. Kandungan inertinit dan liptinit batubara Lapangan $X$ lebih tinggi daripada batubara Lapangan Y. Hasil analisis GI dan 
TPI mengindikasikan, bahwa batubara Lapangan $X$ diendapkan pada lingkungan limnic-marsh hingga limno telmatic sedangkan batubara Lapangan $Y$ mengindikasikan lingkungan limnic marsh hingga telmatic, Secara umum komposisi material organik dan anorganik menunjukkan bahwa pengaruh laut lebih besar pada Lapangan $\mathrm{Y}$.

Batubara di kedua lapangan memiliki mutu yang tidak jauh berbeda, dengan kandungan sulfur dan abu yang terbilang rendah $(<10 \%)$ sehingga dapat digolongkan ke dalam batubara bersih. Hanya conto SJ2 dari Lapangan $X$ yang memiliki kandungan mineral sangat tinggi, mengindikasikan bahwa conto tersebut bukan merupakan batubara.

\section{UCAPAN TERIMA KASIH}

Terima kasih penulis ucapkan kepada Kepala Pusat Sumber Daya Mineral, Batubara dan Panas Bumi yang telah memberikan kesempatan untuk menggunakan conto batubara dan juga fasilitas laboratorium sehingga penelitian ini bisa dilaksanakan dengan baik. Terima kasih juga penulis sampaikan kepada reviewer yang sudah memberikan masukan dan saran sehingga manuskrip ini tersusun lebih baik.

\section{DAFTAR PUSTAKA}

Anderson, J.A.R., 1983. The tropical peat swamps of western Malesia. Mires: swamp, bog, fen and moor, $4 b$ Regional studies.

Amijaya, H. and Littke, R., 2005. Microfacies and depositional environment of Tertiary Tanjung Enim low rank coal. South Sumatera basin, Indonesia, International Journal of Coal Geology, 61(3), pp. 197-221.
Clarke, M.C.G., Kartawa, W., Djunuddin, A., Suganda, E. \& Bagdja, M. 1982b. The Geology of the Pakanbaru Quadrangle (0816), Sumatra, Scale 1: 250000 , Geological Survey of Indonesia, Directorate of Mineral Resources, Geological Research and Development Centre, Bandung.

Darman, H. dan Sidi, F.H., 2000. An Outline of The Geology of Indonesia, Ikatan Ahli Geologi Indonesia.

De Coster, G.L., 1974. The geology of the central and south Sumatra basins.

Diessel, C.F., 1992. Coal-bearing depositional systems. Springer Science \& Business Media.

Flores, R.M., 2013. Coal and coalbed gas: fueling the future. Newnes.

Ginger, D. and Fielding, K., 2005, The petroleum systems and future potential of the South Sumatra Basin.

International Committee for Coal and Organic Petrology, 2001. New inertinite classification (ICCP system 1994), Fuel 80, 459-471.

O'Keefe, J.M., Bechtel, A., Christanis, K., Dai, S., DiMichele, W.A., Eble, C.F., Esterle, J.S., Mastalerz, M., Raymond, A.L., Valentim, B.V. and Wagner, N.J., 2013. On the fundamental difference between coal rank and coal type, International Journal of Coal Geology, 118, pp. 5887.

Parr, S.W. 1928. University of Illinois Engineering Experiment Station Bull. $180,62 \mathrm{pp}$.

Pickel, W., Kus, J., Flores, D., Kalaitzidis, S., Christanis, K., Cardott, B.J., MiszKennan, M., Rodrigues, S., Hentschel, A., Hamor-Vido, M. and Crosdale, P., 2017. Classification of liptinite-ICCP System 1994. International Journal of Coal Geology, 169, pp. 40-61.

Simandjuntak, T.O., Budhitrisna, T., Surono, Gafoer, S., dan Amin, T.C., 1994. Peta Geologi Lembar Muarabungo, Sumatera, sekala 1: 250.000, Puslitbang Geologi, Bandung. 


\section{MAKALAH ILMIAH}

Speight, J.G., 2015. Handbook of coal analysis, John Wiley \& Sons.

Standar Nasional Indonesia 6728.4.2015. Penyusunan Neraca Sumber Daya Alam Spasial, Bagian 4, Sumber daya dan cadangan mineral dan batubara, Badan Standardisasi Nasional.

Suárez-Ruiz, I. and Crelling, J.C. eds., 2008. Applied coal petrology: the role of petrology in coal utilization, Academic Press.
Sýkorová, I., Pickel, W., Christanis, K., Wolf, M., Taylor, G.H. and Flores, D., 2005. Classification of huminiteICCP System 1994. International Journal of Coal Geology, 62(1), pp. 85-106.

Thuzar Win, C., Amijaya, D.H., Surjono, S.S., Husein, S. and Watanabe, K., 2014. A Comparison of Maceral and Microlithotype Indices for Interpretation of Coals in the Samarinda Area, Lower Kutai Basin, Indonesia. Advances in Geology.

\begin{tabular}{|ll|}
\hline Diterima & $:$ 20 Juni 2017 \\
Direvisi & $: 25$ Agustus 2017 \\
Disetujui & $: 29$ Agustus 2017
\end{tabular}

